8. Тищенко О. М. Кластери як вектор розвитку економіки: організація, сутність і концепції. Теоретичні та прикладні питання економіки. 2010. Вип. 21. С. 74-80.

9. Файоль А. Общее и промышленное управление. М.: Контроллинг, 1992.

\title{
References
}

1. Borodin, A. I. Formation of sustainable development of the enterprise of the region: mechanisms, methods, management (ecological-economic aspect), RSU. I. Kant, 2009.

2. Vownarenko, M. "The concept of clusters - the way to the revival of production at the regional level." Economist, no.1, 2000, pp. 12-15.

3. Danylyshyn, Bohdan. "Monetary policy VS economic growth: the competition has dragged on." Mirror of the Week, no. 29, 2019. ZN,UA, https://dt.ua/macrolevel/monetarna-politika-vs-ekonomichnezrostannya-zmagannya-zatyagnulosya-318733_.html. Accessed 10 Sept. 2019.

4. Klebanova, T.S., Kizym, N.A. Models of assessment, analysis and forecasting of socio-economic systems, INZHEK ID, 2010.

5. Kuladzhi, T.V., and A.V. Babkin. "Matrix microprojection of competitiveness of innovative products in the cluster." Scientific and Technical Bulletins of SPbSPU. Economic Sciences, no. 6 (246), 2016, pp. 130-147. DOI: 10.5862 / JE.256.12.

6. Klymchuk, Maryna, and Viktoriya Shovkivska. "Economic and organizational foundations of integration formations: explication of the building energy cluster." Economic Forum: scientific journal, no.1, 2018, pp. 135-140.

7. Klymchuk, Maryna. "Mechanism of investment of enterprises-institutional participants of the construction energy cluster." Business Inform, no.5, 2018, pp. 149-154.

8. Tyshchenko, Oleksandr. "Clusters as a vector of economic development: organization, essence and concepts." Theoretical and applied issues of economics, no. 21, 2010, pp. 74-80.

9. Faiol, A. General and Industrial Management, Controlling, 1992.

УДК 338.242

doi: 10.15330/apred.1.15.35-48

\section{ЗАСТОСУВАННЯ ОСНОВНИХ КОНЦЕПТУАЛЬНИХ ПОЛОЖЕНЬ І ТЕОРІЙ У ПРОЦЕСІ ФОРМУВАННЯ ТА ВІДТВОРЕННЯ ІНТЕЛЕКТУАЛЬНОГО КАПІТАЛУ У СУЧАСНІЙ ПРАКТИЦІ ЗАБЕЗПЕЧЕННЯ КОНКУРЕНТОСПРОМОЖНОСТІ ВІТЧИЗНЯНИХ ПІДПРИЕМСТВ МАШИНОБУДУВАННЯ}

\author{
Тернопільський національний технічний \\ університет імені Івана Пулюя, \\ Міністерство освіти і науки України, \\ кафедра управління інноваційною \\ діяльністю та сферою послуг, \\ вул. Микулинецька, 46, м. Тернопіль, \\ 46000, Україна, \\ тел.: 380964315467 , \\ e-mail: Galinka2005_08@ukr.net
}

\begin{abstract}
Анотація. Стаття присвячена дослідженню застосування основних концептуальних положень і теорій у процесі формування та відтворення інтелектуального капіталу у сучасній практиці забезпечення конкурентоспроможності вітчизняних підприємств машинобудування. Розкрито економічний зміст, мету та форми процесу розвитку інтелектуального капіталу у взаємозв'язку 3 людським капіталом. Проаналізовано наукові підходи до теорії інтелектуального капіталу, на підставі яких теоретично обгрунтовано основні механізми
\end{abstract}


процесів формування та відтворення інтелектуального капіталу сучасних машинобудівних підприємств. Розглянуті теорії людського й інтелектуального капіталу, наведена їхня систематизація. Узагальнено та критично проаналізовано сутнісну характеристику втримування та трансформації інтелектуального капіталу з метою визначення потенційних можливостей зростання для подальшого економічного розвитку у руслі інноваційної парадигми. Виявлено вплив людини та знань на трансформацію інтелектуального капіталу. Досліджено сучасний стан та розкрито особливості формування та відтворення інтелектуального капіталу на підприємствах машинобудівного комплексу України. Уточнено зміст поняття “інтелектуальний капітал підприємство”, дано авторське трактування основних складових інтелектуального капіталу підприємства, які безпосередньо сприяють підвищенню конкурентоспроможності. Розкрито питання управління інтелектуальним капіталом вітчизняних підприємств машинобудування. Визначено ряд проблем, які безпосередньо впливають на формування та відтворення інтелектуального капіталу в машинобудуванні України.

Розвиток інтелектуального капіталу на рівні підприємства суттєво підвищує їхню конкурентоспроможність, дозволяючи знаходити нові можливості по завоюванню ринку. Посилення ролі інтелектуальних ресурсів у розвитку конкурентоспроможності підприємства в економіці знань привело до того, що змінилися умови та способи створення доданої вартості: знання, навички людських ресурсів (людський капітал), організаційні й управлінські здібності підприємства, його компетенції (структурний капітал) перетворилися в основні фактори створення нової вартості та фактично синтезували появу інтелектуального капіталу, який можна розглядати як ключовий елемент конкурентоспроможності підприємства, точніше елемент, що формує потенційну конкурентоспроможність підприємства. Потенціал розвитку конкурентоспроможності підприємства лежить у галузі формування його інтелектуального капіталу. Чим вищий інтелектуальний капітал, тим вища потенційна конкурентоспроможність підприємства. Звідси все частіше при оцінюванні ринкової вартості підприємства на перший план виходить оцінювання таких нематеріальних активів (складових інтелектуального капіталу), як технологічні активи, стратегія бізнесу, корпоративна культура, клієнтський капітал (капітал відносин), репутаційний капітал, капітал бренду тощо.

Ключові слова: капітал, інтелектуальний капітал, складові інтелектуального капіталу, організаційний капітал, соціальний капітал, людський капітал, управлінський капітал, конкурентоспроможність, інновації, економіка знань, машинобудівне підприємство.

\title{
THE APPLICATION OF THE BASIC CONCEPTUAL POSITIONS AND THEORIES IN THE PROCESS OF FORMATION AND REPRODUCTION OF INTELLECTUAL CAPITAL IN MODERN PRACTICE OF ENSURING THE COMPETITIVENESS OF DOMESTIC ENGINEERING ENTERPRISES
}

\author{
Ternopil National Technical \\ University named after Ivan Puliui, \\ Ministry of Education and Science of Ukraine, \\ Department of of Innovation \\ Management activities and services, \\ Mykulynetska str., 46, Ternopil, \\ 46000, Ukraine, \\ tel.: 380964315467 , \\ e-mail: Galinka2005_08@ukr.net
}

\begin{abstract}
The article is devoted to the study of the application of the basic conceptual provisions and theories in the process of formation and reproduction of intellectual capital in the modern practice of ensuring the competitiveness of domestic machine-building enterprises. The economic content, purpose and forms of the process of development of intellectual capital in relation to human capital are revealed. The scientific approaches to the theory of intellectual capital are
\end{abstract}


analyzed, on the basis of which the basic mechanisms of processes of formation and reproduction of intellectual capital of modern machine-building enterprises are theoretically substantiated. Theories of human and intellectual capital are considered, their systematization is given. Essential characteristics of retention and transformation of intellectual capital are summarized and critically analyzed in order to identify potential growth opportunities for further economic development in line with the innovation paradigm. The influence of human and knowledge on the transformation of intellectual capital is revealed. The current state is investigated and features of formation and reproduction of intellectual capital at the enterprises of machine-building complex of Ukraine are revealed. The content of the concept of "intellectual capital of the enterprise" is clarified, the author's interpretation of the main components of the intellectual capital of the enterprise, which directly contribute to the increase of competitiveness, is given. The issue of management of intellectual capital of domestic machine-building enterprises is discussed. A number of problems that directly affect the formation and reproduction of intellectual capital in machine building of Ukraine are identified.

The development of intellectual capital at the enterprise level significantly increases their competitiveness, allowing to find new opportunities to gain market. Strengthening the role of intellectual resources in the development of competitiveness of the enterprise in the knowledge economy has led to a change in conditions and ways of creating value added: knowledge, skills of human resources (human capital), organizational and managerial abilities of the enterprise, its competences (structural capital) have become the main factors creating new value and actually synthesizing the emergence of intellectual capital, which can be seen as a key element of enterprise competitiveness, more precisely an element, which shapes the potential competitiveness of the enterprise. The potential of development of competitiveness of the enterprise lies in the field of formation of its intellectual capital. The higher the intellectual capital, the higher the potential competitiveness of the enterprise. Hence, more and more often, valuation of intangible assets (components of intellectual capital), such as technological assets, business strategy, corporate culture, client capital (relationship capital), reputational capital, brand equity, etc., comes to the fore when assessing the market value of the enterprise.

Key words: capital, intellectual capital, components of intellectual capital, organizational capital, social capital, human capital, managerial capital, competitiveness, innovation, knowledge economy, machine-building enterprise.

Вступ. В умовах розвитку інноваційної економіки динаміка виробничих нововведень в усе зростаючій мірі забезпечується спеціально організованою інтелектуальною діяльністю людської особистості, у межах якої відбуваються осмислення та вивчення практичного досвіду. Завдяки цьому накопичений інтелектуальний капітал стає все більш важливим фактором конкурентоспроможності, a, значить, сталого розвитку держав і підвищення добробуту їх населення. По суті, він із завдання створення економічного блага поступово трансформується у мету й умови ïx розширеного відтворення. При цьому повинен спрацювати ефект масштабності, коли сформована ідея буде застосовуватися не лише відносно окремих людей або групи осіб у межах локального співтовариства, а на все суспільство у цілому. Тому представляється доцільним сфокусувати науковий інтерес на таких аспектах економічного розвитку, де передбачається особиста участь людської особистості 3 високим рівнем професійної підготовки, а також наявність сприятливих умов для якісного відтворення інтелектуального капіталу. Разом з тим, не варто упускати 3 поля зору той факт, що інтелектуальний капітал як фундаментальна основа інноваційної економіки має ряд досить цікавих властивостей. Насамперед, він досить важко керується адміністративними методами, оскільки закладається довгостроковими соціально-економічними стратегіями, а також погодженою діяльністю економічних систем і соціальних інститутів.

Процес формування та відтворення якісного інтелектуального капіталу в умовах розвитку інноваційної економіки неможливий без наявності якісного людського потенціалу, нагромадження якого досягається через систему обов'язкових i 
взаємозалежних між собою складових: морально-етичного виховання, фізіологічного, а також професійної освіти. При цьому найбільш затребуваною з економічної точки зору складовою виступає, безумовно, остання - професійна. Незважаючи на всебічну інтелектуалізацію суспільства, проблему визначення економічної сутності інтелектуального капіталу та механізмів його відтворення ще недостатньо вивчено [4].

Різноманітним аспектам формування та розвитку інтелектуального капіталу в тих або інших конкретно-історичних умовах присвячена велика кількість праць закордонних і вітчизняних дослідників. Істотний внесок у первісне становлення та наступний розвиток еволюційної концепції інтелектуального капіталу 3 боку закордонної економічної думки внесли такі дослідники, як: Г. Беккер, С. Денісон, Дж. Мінцер, Т. Стоуньєр, Є. Тоффлер, Л. Туроу, Т. Шульц й ін. Серед вітчизняних дослідників особливо хотілося б відзначити таких відомих дослідників, як: В. Д. Базилевича [1], В. Баранчеєва [2], Ю. А. Варфоломеєвої [3], А. В. Сременко [4], І. В. Левіної [8], Л. Г. Мельника [10], С. М. Ілляшенко [10], В. А. Касьяненко [10], І. В. Терона [12], А. Ю. Мазарчука [9], І. І. Ткача [9], В. В. Циганова [13], В. А. Бродіна [13], Г. Б. Шишкіна [13] та ін. Питання дослідження людського капіталу у взаємозв'язку 3 інтелектуальним капіталом висвітлені у працях Дж. Кендрика, Ф. Махлупа, Дж. Мінцера, М. Мелоуна, Т. Стюарта й ін. У зв'язку 3 концепцією формування інноваційної економіки актуальність наукового осмислення ролі інтелектуального капіталу в економічному розвитку набула нових можлдивостей. Дана проблематика виникла разом з усвідомленням того факту, що знання стають тією перспективною галуззю, у якій уточнюється категоріальна сутність людського буття по найбільш принципових питаннях. Посилення економічного значення знань у виробничому процесі природнім чином сприяло появі теорій, що ставлять у центр уваги саме цей фактор. Серед різних концепцій "нового" суспільства, які послідовно змінювали одна одну із другої половини минулого століття, можна виділити чотири основні напрямки: теорія постіндустріального суспільства (Д. Белл, 3. Бжезинський, А. Кумарасвамі, Д. Рісмен); теорія постмодернізму (Ж. Бодійяр, М. Постер); теорія інформаційного суспільства (М. Кастельс, Й. Масуда, Ф. Махлуп, Р. Меткалф, М. Порат, Т. Сакайя, Т. Стоуньєр) і теорія розвитку суспільства знання (П. Друкер, Є. Тоффлер, Дж. Ходжсон).

Л. Г. Мельник визначає інтелектуальний капітал як інтелектуальні здатності людей, у сукупності зі створеними ними матеріальними й нематеріальними засобами, які використовуються в процесі інтелектуальної праці [10]. У свою черу, С. М. Ілляшенко зазначає, що: “Інтелектуальний капітал - вартість сукупності наявних у нього інтелектуальних активів, зокрема інтелектуальної власності, його природних i придбаних інтелектуальних здібностей і навичок, а також накопиченої ним бази знань i корисних відносин з іншими суб'єктами" [5]. В. Д. Базилевич [1] вважає, що інтелектуальний капітал (ІК) як провідний чинник та основа інтелектуальної економіки має певні специфічні ознаки. До таких ознак він відносить наступні: інтелектуальний капітал не $\epsilon$ матеріальним у традиційному розумінні; інтелектуальний капітал перебуває одночасно у формах запасу і продукту; інтелектуальний капітал зберігається та нагромаджується у специфічних традиційних формах; інтелектуальний капітал $є$ основним компонентом визначення ринкової вартості підприємств.

Визнаючи високу значимість досліджень перерахованих учених у контексті обкресленої проблематики, варто разом з тим відзначити, що теорія та методологія формування та розвитку інноваційного інтелектуального капіталу в Україні перебуває у процесі становлення, а основні методи його оцінювання запозичені головним чином із західної практики та не завжди адаптовані до умов української економіки. Недостатньо вивчена виробнича роль інтелектуального капіталу та його трансформація в умовах розвитку інноваційної економіки, у т. ч. питання втримування трансформації, 
взаємозв'язків інтелектуального капіталу з інноваційним розвитком, формування інноваційної людини, розроблення практичного інструментарію для забезпечення результативності й активізації людського капіталу як основної складової інтелектуального капіталу тощо.

Суперечливість різних концептуальних підходів, нестача емпіричних досліджень гальмують впровадження теорії та методології інтелектуального капіталу в систему управління та подальших досліджень у цій галузі. Таким чином, актуальність й об'єктивна необхідність системного обгрунтування та комплексного вирішення теоретичних і прикладних проблем дослідження й оцінювання інтелектуального капіталу як найважливішого конкурентоспроможного фактору економічного розвитку обумовили формування мети та завдань нашого дослідження. Якщо економіка XX століття визначалася технократичною спрямованістю, то економіка XXI століття поступово трансформується в економіку знань. Не применшуючи значимості матеріальних ресурсів у процесі виробництва, більшість дослідників сьогодні солідарні 3 думкою, що капіталізація їх вартості формується під серйозним впливом нематеріальних ресурсів. I хоча господарська діяльність за всіх часів базувалася на класичних факторах виробництва, фактор інтелектуального капіталу на сьогоднішній день $є$ найважливішим.

Нагромадження й активізація інтелектуального капіталу дозволяє ефективно виконувати певний вид роботи й бути готовим до зростаючих вимог праці. Люди швидше пристосовуються до змін, освоюють нововведення та користуються інноваціями. Завдяки нагромадженню інтелектуального капіталу прискорюються темпи прогресу. Останнє сприяє подальшому поширенню та прискоренню генерування нових знань і компетенцій. При побудові національної інноваційної системи продуктивні сили людини реалізовуються у формі інтелектуального капіталу. Істотним активом, що й набирають чинність, тут виступає освіта. Даний актив стає близьким до понять інноваційно-орієнтованого економічного зростання, ринкового успіху, науковотехнічного й еволюційного потенціалу, що супроводжується підвищенням ролі та місця нових проривних наукових знань й інформації. Дійсність така, що на сьогоднішній день перевага багато у чому визначається рівнем освіти й обсягом сконцентрованих у соціумі знань і компетенцій.

А. Смітом уперше був зроблений висновок про пряму залежність між професійним рівнем підготовки працівника з його вихованням і ростом продуктивності праці. Обгрунтовуючи свою позицію, дослідник відзначає, що "збільшення продуктивності корисної праці залежить, насамперед, від підвищення спритності й уміння робітника, а потім від поліпшення машин і інструментів, за допомогою яких він працює". А. Сміта як дослідника, особливо цікавить джерело походження високих доходів тих, хто володіє більшими вміннями, знаннями та вправністю. У своїх міркуваннях він виходить із того, що “знання, досвід і вміння, а також придбані та корисні здібності всіх жителів і членів суспільства” представляють собою своєрідний капітал - основний капітал. Особливість даного капіталу укладається в тому, що “він приносить прибуток або вигоду, не надходячи в обіг або не змінюючи власника”, тобто накопичені знання та компетенції здатні приносити його власникові реальний дохід, при цьому, не виступаючи об'єктом купівлі-продажу. Дослідника хвилює також процес становлення та нагромадження основного капіталу як на рівні окремо взятої особистості, так і на рівні всієї країни. Безумовно, для їхнього виникнення необхідні певні вкладення грошей i часу. Ключовою формою капіталовкладень у корисні здібності особистості визнавалися інвестиції у виховання й освіту, завдяки яким з'являлася можливість удосконалювати й розбудовувати власну порівняльну перевага. Крім того, нагромадження необхідних знань і компетенцій у процесі навчання 
гарантують у майбутньому його власникові більш високі доходи по відношенні до менш освічених людей.

Інтерес до управління знаннями в останнє десятиріччя значно зріс. Наприклад, професор Маринко Г. І. зробив системний огляд різноманітних моделей та шкіл в управлінні знаннями [2]. Він виділив наступні школи: системну; картографічну; процесну; комерційну організаційну; просторову; - стратегічну. А на думку професора Майкла Єрла, всі школи можна згрупувати в три основні категорії, а саме: технократичні підходи, економічні підходи, біхевіористські [2].

Підприємства, на наш погляд, не володіють інтелектуальним капіталом повністю. Вони мають його разом з персоналом (якщо мова йде про людський капітал), разом зі споживачами, партнерами (споживчий капітал). Можна зробити висновок, що інтелектуальний капітал не функціонує окремо. Його неможливо розділити на частини так, щоб їх сума дорівнювала сукупній оцінці інтелектуального капіталу підприємства. Взаємодія різних складових носить нелінійний характер. Наприклад, не завжди чисто людський компонент достатній для формування потужного інтелектуального капіталу підприємства. Для цього необхідно високу компетентність працівників доповнити відповідними елементами організаційного капіталу - такими, як організаційна структура, сучасні комп'ютерні технології, устаткування, ефективні управлінські технології тощо. Людський, організаційний і споживчий капітали взаємозалежні. Немає змісту вкладати кошти в якийсь із них окремо. Вважаємо, що вони повинні розбудовуватися у сукупності, створюючи синергетичний ефект.

У цілому багато дослідників дотримувалися думки, що втілені у виробничому процесі людські здібності та компетенції правомірно враховувати в якості капіталу. Таким чином, до другої половини ХX століття формуються необхідні передумови й основні елементи теорії, закладаються методологічні основи та окреслюються ключові напрямки розвитку концепції інтелектуального капіталу.

Формування концепції інтелектуального капіталу та іiі виділення як самостійного напрямку світової економічної думки було обумовлено структурними змінами у соціальному й економічному житті суспільства, викликаними науково-технічним прогресом. Із другої половини минулого століття на порядок денний постає нагальна потреба у висококваліфікованих кадрах. Це обумовило необхідність кардинального переосмислення значення утвору, наукових знань, досвіду й ролі складної інтелектуальної праці. На основі зробленого огляду концепцій людського та інтелектуального капіталу систематизовано теоретичні погляди (табл. 1).

Таблиия 1

Еволюція наукової думки у процесі розвитку теорій людського й інтелектуального капіталу (складено автором)

Table 1

The evolution of scientific thought in the development of theories of human and intellectual capital (developed by the author)

\begin{tabular}{|c|c|c|}
\hline $\begin{array}{c}\text { Концепції людського й } \\
\text { інтелектуального капіталу }\end{array}$ & Коротке трактування концепції & Дослідники \\
\hline 1 & 2 & 3 \\
\hline \begin{tabular}{|l} 
Tеорії людського капіталу \\
(1960-1961 рр.)
\end{tabular} & $\begin{array}{l}\text { Вплив освіти, знань працівників, } \\
\text { інвестиції в людський капітал }\end{array}$ & $\begin{array}{l}\text { T. Шульц, } \\
\text { М. Боуман }\end{array}$ \\
\hline $\begin{array}{l}\text { Теорія людського капіталу } \\
\text { (1962-1964 рр.) }\end{array}$ & $\begin{array}{l}\text { Оцінка значимості знань і } \text { вмінь } \\
\text { працівників у процесі трудової діяльності } \\
\text { та відтворення }\end{array}$ & Г. Беккер \\
\hline
\end{tabular}


Продовження табл.1

\begin{tabular}{|c|c|c|}
\hline $\begin{array}{l}\text { Теорія людського капіталу } \\
\text { (1970-1985 рр.) }\end{array}$ & $\begin{array}{l}\text { Видатки на навчання розглядаються як } \\
\text { капіталовкладення, нагромадження знань, } \\
\text { навичок - як нагромадження людського } \\
\text { капіталу. }\end{array}$ & $\begin{array}{l}\text { Б. Вейсборд, } \\
\text { Л. Туроу, } \\
\text { У. Боуен, } \\
\text { М. Фішер }\end{array}$ \\
\hline $\begin{array}{l}\text { Теорія людського капіталу } \\
(1990 \text { рр. - по сьогоднішній } \\
\text { час) }\end{array}$ & $\begin{array}{l}\text { У центрі теорій - додана вартість, яку } \\
\text { працівники можуть створювати для } \\
\text { організації. Працівники розглядаються як } \\
\text { активи підприємства, і ї слід розглядати } \\
\text { скоріше як доходи, ніж видатки. }\end{array}$ & $\begin{array}{l}\text { М. Блауг, } \\
\text { С. Боулс, } \\
\text { Б. Чизвик, } \\
\text { А. Аулін, } \\
\text { В. Ванг }\end{array}$ \\
\hline $\begin{array}{l}\text { Tеорія людського капіталу } \\
(1990-\mathrm{i} \quad \text { рр. } \\
\text { сьогоднішній час) }\end{array}$ & $\begin{array}{l}\text { Ресурсоорієнтований підхід до фірми - } \\
\text { стійкої конкурентної переваги можна } \\
\text { досягти тоді, коли у фірми є запас } \\
\text { людських ресурсів, якого немає у }\end{array}$ & Д. Барней \\
\hline \begin{tabular}{|lrr} 
Теорія & інтелектуального \\
капіталу & \multicolumn{2}{r}{ підприємства } \\
$(1990-\mathrm{i}$ & рр. & - \\
сьогоднішній час) & & по
\end{tabular} & $\begin{array}{l}\text { Інтелектуальний капітал представляє } \\
\text { собою сукупність знань, які здатні } \\
\text { створювати організації додаткову вартість. } \\
\text { Т. Стюарт включив у структуру } \\
\text { інтелектуального капіталу людський й } \\
\text { організаційний капітал }\end{array}$ & Т. Стюарт \\
\hline $\begin{array}{l}\text { Теорія інтелектуального } \\
\text { капіталу підприємства (1997 } \\
\text { p. - по сьогоднішній час) }\end{array}$ & $\begin{array}{l}\text { Інтелектуальний капітал породжений } \\
\text { ресурсом, яким компанія не в змозі } \\
\text { володіти - iї працівниками. Розглянуті } \\
\text { проблеми виявлення, оцінки й управління } \\
\text { інтелектуальним капіталом на прикладі } \\
\text { компанії "Scandia". Запропонована } \\
\text { структура інтелектуального капіталу: } \\
\text { структурний капітал (капітал клієнта й } \\
\text { організаційний капітал), людський капітал }\end{array}$ & $\begin{array}{l}\text { Л. } \\
\text { Едвінссон } \\
\text { М. Мелоун }\end{array}$ \\
\hline \begin{tabular}{llr} 
Tеорія & інтелектуального \\
капіталу & \multicolumn{2}{r}{ підприємства } \\
$(1990-$ i & рp. & - \\
сьогоднішній час) &
\end{tabular} & $\begin{array}{l}\text { Трьохкомпонентна } \\
\text { iнтелектуального концепція } \\
\text { капітал, організаційний, соціальний }\end{array}$ & $\begin{array}{l}\text { М. Юндт, } \\
\text { Р. Дафт, } \\
\text { К. Уейт, } \\
\text { Р. Шуллер }\end{array}$ \\
\hline $\begin{array}{ll}\text { Теорія } & \text { інтелектуального } \\
\text { капіталу (1990-i pp. - по } \\
\text { сьогоднішній час) }\end{array}$ & $\begin{array}{l}\text { Розроблений підхід до структури } \\
\text { інтелектуального капіталу: зовнішня } \\
\begin{array}{l}\text { структура, внутрішня, індивідуальна } \\
\text { компетентність }\end{array}\end{array}$ & К. Свейбі \\
\hline \begin{tabular}{|lrr} 
Теорія & інтелектуального \\
капіталу & \multicolumn{2}{r}{ підприємства } \\
$(1990-i$ & рр. & - \\
сьогоднішній час) & & по
\end{tabular} & $\begin{array}{l}\text { Запропонована наступна структура } \\
\text { інтелектуального капіталу: нематеріальні } \\
\text { ринкові активи, активи інтелектуальної } \\
\text { власності, активи інфраструктури, } \\
\text { гуманітарні активи }\end{array}$ & $\begin{array}{l}\text { А. Брукінг, } \\
\text { Е. } \\
\text { Марнотрата }\end{array}$ \\
\hline
\end{tabular}


Продовження табл.1

\begin{tabular}{|c|c|c|}
\hline \begin{tabular}{|lrr} 
Tеорія & інтелектуального \\
капіталу & \multicolumn{2}{r}{ підприємства } \\
$(1990-\mathrm{i}$ & рp. & - \\
сьогоднішній час) &
\end{tabular} & $\begin{array}{l}\text { Iнтелектуальний капітал підприємства містить: } \\
\text { людський капітал, що існує в працівниках у } \\
\text { формі досвіду, знань, умінь, навичок, } \\
\text { здібностей до інновацій, у загальній культурі; } \\
\text { структурний капітал, що випливає з патентів, } \\
\text { торговельної марки, організаційної структури } \\
\text { управління, інформаційних баз }\end{array}$ & $\begin{array}{l}\text { В.Л. } \\
\text { Іноземцев }\end{array}$ \\
\hline 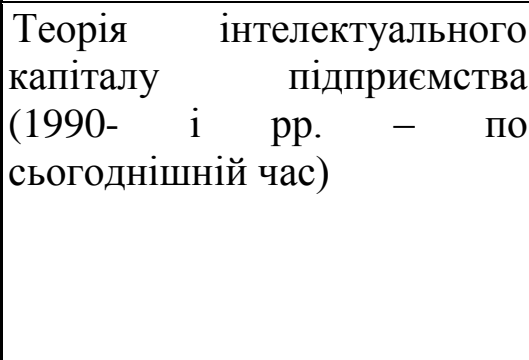 & $\begin{array}{l}\text { Під інтелектуальним капіталом підприємства } \\
\text { розуміється вартість інтелектуальних активів } \\
\text { (інтелектуальна власність, інтелектуальні } \\
\text { здібності, накопичена інформація та взаємини } \\
\text { 3 іншими суб'єктами). Інтелектуальний капітал } \\
\text { складається } 3 \text { людського й організаційного } \\
\text { капіталів, головною складовою вважає } \\
\text { організаційний капітал }\end{array}$ & В.Б. Ле \\
\hline 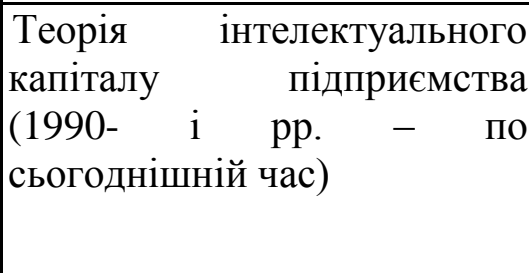 & $\begin{array}{|lcr|}\text { Розроблена } & \text { наступна } & \text { структура } \\
\text { iнтелектуального } & \text { капіталу: } & \text { людський, } \\
\text { клієнтський і організаційний } & \end{array}$ & $\begin{array}{l}\text { Український } \\
\text { інститут } \\
\text { інтелектуаль- } \\
\text { ної } \\
\text { власності і } \\
\text { права }\end{array}$ \\
\hline
\end{tabular}

Як видно 3 табл. 1, теоретичні погляди на людський і інтелектуальний капітал розбудовуються приблизно протягом 50 років, спочатку з'явилися теорії людського капіталу, а пізніше теорії інтелектуального капіталу. На підставі проведеного дослідження теорій людського й інтелектуального капіталу, пропонуємо наступний підхід до розуміння ролі та місця інтелектуального капіталу на сучасному підприємстві. Вивченням проблеми формування та розвитку інтелектуального капіталу поряд із західними дослідниками, займалася й українська економічна наука. При цьому вітчизняними дослідниками був зроблений досить вагомий внесок у розвиток названої теми. Його специфіка визначається особливою ментальністю, культурою та традиціями, що сформувалися самобутніми національними звичаями та вдачами українського народу, його відношенням до праці, нагромадження багатства, до процесу отримання освіти, заснованими на комбінації духовно-моральних i матеріальних цінностей. Особливо слід зазначити, у XVII - XVIII ст. українськими вченими вводяться в науково-економічний обіг такі поняття, як моральний і нематеріальний капітал, що характеризують становлення та зростання національного багатства, заснованого на органічній комбінації творчих і інтелектуальних цінностей і знань людської особистості. У прагненні зрозуміти та розгадати природу людської особистості, наукові погляди української інтелігенції багато в чому перетиналися 3 образами й ідеями мислителів античності, яким було властиве розуміння моральності та духовного розвитку особистості як основи гармонійного розвитку суспільства та держави у цілому.

С. М. Ілляшенко у складі інтелектуального капіталу виділяє лише дві складові [5]: людський капітал: знання, практичні навички, досвід, ноу-хау, творчі здібності, креативний спосіб мислення, моральні цінності, загальна культура; та структурний капітал: технічне і програмне забезпечення, організаційна структура, патенти, ліцензії, ноу-хау, товарні знаки, промислові зразки, технічне й програмне забезпечення, організаційна структура, корпоративна культура, відносини 3 клієнтами, зв'язки 3 економічними контрагентами (постачальниками, споживачами, посередниками, 
кредитно-фінансовими установами, органами влади тощо), інформація про економічних контрагентів, історія взаємин з економічними контрагентами, торгова марка (бренд).

Зазвичай машинобудування класифікують як галузь зі середнім рівнем наукоємності. При цьому грунтуються на тому факті, що частка витрат на НДДКР становить близько 2\% вартості продукції і залишається на цьому рівні вже більше десяти років. У порівнянні з іншими інноваційними галузями, такими як ІКТ або фармацевтика, цей показник виглядає порівняно низьким. Більше того, технології, використовувані в машинобудуванні, часто оцінюються як “зрілі”. Така точка зору не враховує “забезпечуючого" характеру машинобудування. Галузь $\epsilon$ ключовою для поширення передових машин, устаткування і виробничих процесів в інших галузях економіки. Велика частина біо- і нанотехнологій, виробництва сучасних матеріалів, мікро- та фотоелектроніки - всього того, що забезпечує конкурентоспроможність, значною мірою залежить від інновацій у машинобудуванні. Інноваційні продукти випускаються 3 використанням машин i устаткування, що постачається машинобудуванням, для чого необхідна тісна взаємодія між виробниками машин i споживаючими галузями. Нові виробничі технології розробляються компаніями на основі ключових “забезпечуючих" технологій спільно з виробниками обладнання та постачальниками необхідних матеріалів. Займаючи у даному випадку верхні сегменти ланцюжків доданої вартості, машинобудування забезпечує виробничими ноу-хау замовників, що знаходяться на нижніх рівнях таких ланцюжків. При цьому широке використання в економіці цих ноу-хау потребує машинобудівних підприємств, які розробляють специфічні рішення для певних галузей або навіть конкретних компаній.

Управлінська діяльність виявляє визначальне значення на розвиток інтелектуального капіталу та на ефективність діяльності підприємства у цілому. Розвиток інтелектуального капіталу повинен бути обміркованим процесом, яким керує менеджмент підприємства. Приведемо слова Т. Сакайа: “Інтелектуальний капітал - це об'єднання воєдино людських здібностей, знань і інформації. Знання, здібності та інформація поєднуються завдяки менеджменту”. Із цього погляду, пропонуємо ввести в науковий обіг поняття управлінського капіталу та включити його у структуру інтелектуального капіталу підприємства. Управлінський капітал можна визначити як сукупність управлінських здібностей, знань, умінь, досвіду, що дає можливість отримувати дохід. Управлінський капітал складається з управлінських працівників (менеджерів) і управлінських рішень (продуктів управлінської праці).

Заходи, здійснювані керівництвом підприємств машинобудування, 3 метою вдосконалення процесу організації праці, проводяться у межах організаційноуправлінських інновацій, які передбачають нововведення у системі управління підприємством. Варто виявити певні закономірності організаційно-управлінських інновацій у взаємозв'язку 3 цілями функціонування підприємства. Результат організаційно-управлінських інновацій у значній мірі залежить від обсягу вкладеного в їх створення та реалізацію інтелектуального ресурсу, що аргументує важливість процесів оцінювання та порівняння інтелектуального потенціалу працівників.

Для ефективного управління інтелектуальним капіталом необхідна побудована повномасштабна система, яка б, на думку Ю. А. Варфоломеєвої [3], з якою ми погоджуємось, вирішувала наступні завдання: підвищення конкурентоспроможності бізнесу; системний розвиток персоналу; підвищення цінності людського ресурсу; удосконалення бізнес-процесів; підтримка управлінських рішень в стратегічному, інноваційному, фінансовому, технологічному і виробничому менеджменті.

На думку А. В. Сременко [4], управління інтелектуальним капіталом повинно бути спрямоване на приведення у відповідність внутрішніх можливостей його 
реалізації і розвитку до зовнішніх, які генеруються ринком. Для того, щоб можна було успішно управляти інтелектуальним капіталом необхідно, на думку А. В. Сременко [4], слід виконати наступні умови: створити передумови для комерціалізації знань; створити належні умови для здійснення інвестицій у форму нематеріальних активів у високотехнологічні галузі та виробництва, що сприяє піднесенню на якісно новий рівень процесу трансферу технологій з-за кордону; раціональніше використовувати інтелектуальні ресурси країни, що в умовах захисту інтелектуальної власності стають дорожчими; створити умови для налагодження ефективної міжнародної кооперації у високотехнологічних галузях i виробництвах, інтеграції країни в регіональний i світовий технологічний простір; покращити умови праці, створити сприятливе середовище для результативної роботи; проводити навчання персоналу, курси підвищення кваліфікації, тренінги, брати участь у міжнародних зборах, конференціях, симпозіумах, що присвячені проблемам галузі/ринку, на якому функціонує підприємство; прийняти закони, які б регулювали питання, які пов'язані 3 інтелектуальним капіталом та використанням професійних та творчих здібностей працівників в організації; запровадити форми звітності, які б відображали користування інтелектуальним капіталом [4].

Очевидно, що праця менеджера має відмінності від інших видів людської діяльності. Ініціативність, комунікабельність, новаторство, організаторські здібності та бажання брати відповідальність, раціональність, лідерські якості необхідні для ефективного управління. Суттєве значення й унікальність таких здібностей визнають більшість економістів, починаючи 3 Й. Шумпетера до сучасних теоретиків неоінституціоналізму. Управлінські переваги - володіння ресурсами, ноу-хау, комерційними секретами - дозволяють перетворити їх в особливий вид інтелектуального капіталу - управлінський капітал. Якість управлінських здібностей, умінь, дій, навичок оцінюється по ефективності використання капіталу, у тому числі, й інтелектуального, а також ефективності діяльності підприємства у цілому. Інтервали прибутковості вкладень капіталу та темпи економічного зростання підприємств свідчить про реальну капіталізацію управлінських здібностей, знань, умінь, навичок.

Вважаємо, що управлінський капітал - один 3 найбільш перспективних i важливих складових інтелектуального капіталу підприємства. Інвестиції у його розвиток $є$ все більш продуктивними. Уміння керувати, організовувати, координувати складна діяльність, вивченням якої сьогодні займаються психологи, соціологи, економісти. Класик менеджменту П. Друкер писав: “Саме менеджмент створює економічний і соціальний розвиток. Він є його результатом. Усюди, де ми вкладали тільки економічні фактори виробництва, ми не домагалися розвитку. У деяких випадках, коли ми змогли породити енергію менеджменту, ми породжували стрімкий розвиток. Розвиток, іншими словами, - справа скоріше людської енергії, ніж економічного багатства. Генерування людської енергії та додання їй напрямку $\epsilon$ завданням менеджменту".

У межах інтелектуального капіталу вчені виділили “людський капітал” i “структурний капітал”. Ми погоджуємось 3 точкою зору О. Кендюхова стосовно того, що вчені підкреслюють те, що кожна 3 цих форм “капіталу” породжена людськими знаннями, і саме їх сукупність визначає приховані джерела цінності, які наділяють компанію нетрадиційно високою ринковою оцінкою.

Вважаючи управління базою для створення підприємств, що відповідають по своєму розвитку сучасним вимогам, слід зрівняти наявні управлінські технології та ті, які потрібно застосовувати для досягнення успішності підприємства. Важливим $є$ формування, розвиток і нагромадження управлінського капіталу підприємств в Україні. Ірунтуючись на вищесказаному, ми дійшли висновку, що людський, управлінський і 
організаційний, соціальний капітал є основними складовими інтелектуального капіталу підприємства. На рис. 1 зображена пропонована структура інтелектуального капіталу підприємства.

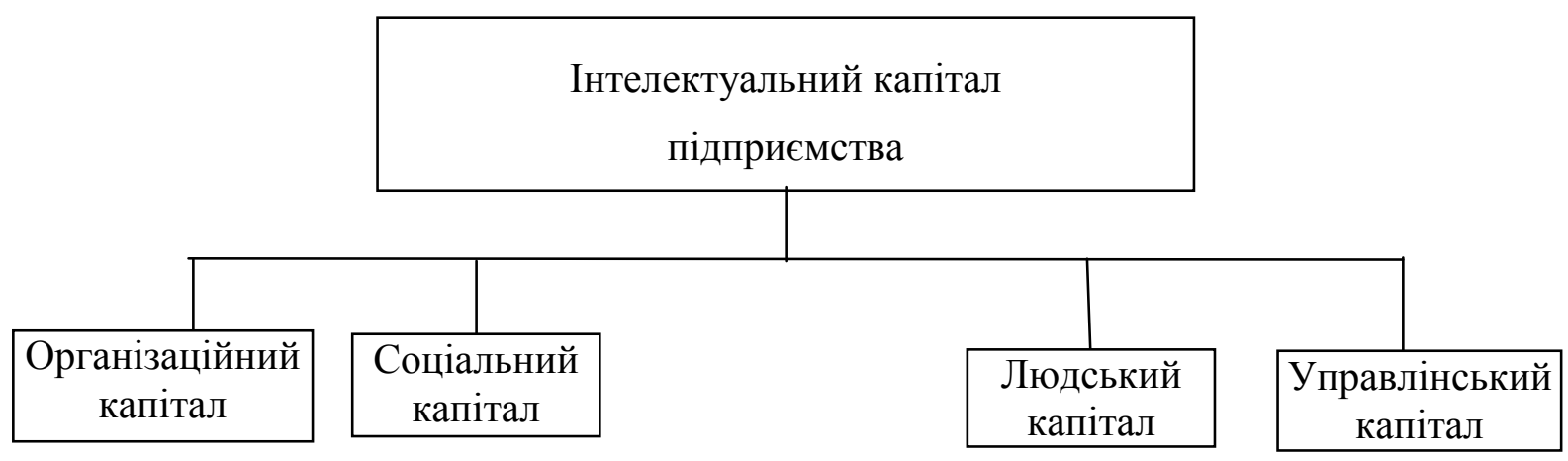

Puc.1. Пропонована структура інтелектуального капіталу підприємства

Fig. 1. The proposed structure of the intellectual capital of the enterprise

Вважаємо, що теорія інтелектуального капіталу підприємства зосереджена на практичних питаннях, пов'язаних із забезпеченням трудовими ресурсами, розвитком i винагородою, аналізуванням руху людських ресурсів, організаційним навчанням i управлінням знаннями. Хоча може здатися, що вона підтримує “тверду" філософію управління людськими ресурсами, яка трактує працівників як активи, вона, однак, змінює те, що вважається найменш привабливим у теорії управління людськими ресурсами, підкреслюючи, що ці “активи” не належать підприємству. Теоретично люди можуть вкладати кошти у власне майбутнє та обирати, як і куди робити інвестиції. На практиці їх можливості щодо цього обмежені багатьма обставинами, але, що стосується кваліфікованих працівників, вони чітко можуть це робити, і цей факт необхідно враховувати при розробленні стратегій забезпечення ресурсами та розвитку людських ресурсів. Виходячи 3 організаційних перспектив, теорія інтелектуального капіталу підприємства ставить наступні практичні питання: якими навичками володіє персонал; які навички необхідні зараз i y майбутньому; яким чином можна здобувати, розбудовувати та зберігати ці навички; як можна формувати культуру та середовище, у яких організаційне й індивідуальне навчання відбувалося б і в інтересах підприємства та в інтересах працівників; яким чином можна забезпечити, щоб знання, створені на підприємстві, як експліковані, так і приховані, здобувалися, зберігалися й ефективно використовувалися. Якщо говорити про окремих людей, то ця теорія підкреслює, що вони мають право очікувати, по-перше, гідного доходу від власних інвестицій у підприємство у вигляді свого часу та зусиль (розвитку їх навичок і здібностей) i, подруге, можливості підвищувати свою професійну затребуваність як усередині, так i поза підприємством.

На наш погляд, теоретичну позицію українських дослідників відрізняє більш точне розмежування сутнісної характеристики інтелектуального капіталу, а також його основних видів і процесу відтворення у ланцюжку: формування - нагромадження соціалізація - активізація - наповнення - інвестування. Критикуючи західну модель розвитку, а також висвітлюючи іiі істотні недоліки та недоопрацювання, українські вчені по-своєму трактують значення категорії “інтелектуальний капітал”. Його специфіка розкривається завдяки вивченню моральної складової, яка не враховувалася західними дослідниками. Таким чином, інтелектуальний капітал по своїй змістовній структурі та сутнісній характеристиці представляє собою сукупність накопичених людиною знань, умінь і компетенцій, здатних приносити його власникові дохід. Ми 
згідні 3 думкою про те, що на сьогоднішній день назріла необхідність у більш всебічному осмисленні даної категорії. Пов'язано це з тим, що на сьогоднішній день відсутня єдина думка по визначенні та розумінні серед дослідників даної категорії, що пояснюється складністю та багатоаспектністю даного феномену. На наш погляд, у кожному дослідженні можуть бути присутні певні погляди, і одночасно охопити їх разом не представляється можливим. Підводячи підсумок критичному аналізуванню категорії інтелектуального капіталу, можна стверджувати, що на сьогоднішній день мають право на життя дещо відособлені та суперечливі між собою підходи, кожний 3 яких наповнює інтелектуальний капітал власними компонентами та відмінними властивостями.

Висновки. 3 переходом на сучасний етап розвитку економіки підвищується значення інтелектуального капіталу. Розвиток інтелектуального капіталу базується на перетворенні інформації та знань у фактори, які здатні створювати багатство та вартість за рахунок кумулятивного ефекту від розвитку організаційного, соціального, людського капіталу. Саме 3 інформації й знань починається ланцюжок формування конкурентної переваги. Розвиток концепції інтелектуального капіталу почався ще в 17 ст. і триває до сьогоднішнього часу. Існує величезна кількість авторських визначень $\mathrm{i}$ класифікацій, обумовлених практичними та професійними інтересами дослідників. Таким чином, поняття “інтелектуальний капітал” пройшло довгий і неоднозначний шлях в історичному розвитку, перш ніж воно остаточно сформувалося та перейшло в економічну категорію й увійшло в науковий обіг. Концепція інтелектуальногокапіталу не завершена, вона безупинно розбудовується, уточнюється та доповнюється. Значення вдосконалювання механізму його послідовного формування й функціонування в умовах інноваційного розвитку неухильно зростає.

Еволюційна теорія інтелектуального та людського капіталу, на наш погляд, потребує більш ретельного вивчення питань закономірностей формування та функціонування інтелектуального та людського капіталу, умов і факторів забезпечення результативності їх використання на всіх етапах розвитку економічної системи: генерація знань - створення та поширення технологій - виробництво інноваційної продукції. Назріла необхідність вирішення складного та багатогранного завдання побудови теоретико-методологічної теорії зміни відносин по формуванню й функціонуванню інтелектуального та людського капіталу, а також розроблення практичного інструментарію для забезпечення подальшої результативності й активізації цих економічних категорій.

Еволюційна складова концепції інтелектуального капіталу розкриває якісні аспекти розвитку питань нагромадження інтелектуального капіталу, враховуючи, що будь-яка економічна система, перебуваючи під впливом зовнішніх рушійних сил, змушена постійно адаптуватися, коректуючи своє системне призначення. Відповідно, відбувається видозміна сутнісного початку як фактору нагромадження та реалізації інтелектуального капіталу, яке впливає на появу внутрішньої різнобічності якості інтелектуального капіталу: особистісного потенціалу суб'єкта, трудового потенціалу економічних відносин, що відображають комплекс дій між працівником, організацією та державою з приводу реалізації трудового потенціалу фахівця та розподілу між ними отриманої доданої вартості.

Еволюція концепції інтелектуального капіталу у структурі соціальноекономічних систем багато у чому визначається ментальною, культурною, інституціональною, когнітивною, технологічною й історичною підсистемами. Кожна 3 них впливає на формування та удосконалювання інтелектуального капіталу: вибудовується ментальна конструкція інтелектуального капіталу, формуються культурні цінності та феномени, інститути, знання та компетенції. Можна припустити, 
що у кожний конкретний історичний період основну роль у нагромадженні та реалізації якісного інтелектуального капіталу починають відіграти кожна із цих структурних підсистем. Теорія формування та розвитку інтелектуального капіталу визначає ознаки еволюційності, що розкривається у внутрішньому та безперервному коректуванні складових його структурних елементів на предмет відповідності новим умовам економічного розвитку. Еволюційна теорія інтелектуального капіталу націлена на серйозне доопрацювання питань закономірностей формування та функціонування інтелектуального капіталу, а також умов і факторів забезпечення результативності використання інтелектуального капіталу на всіх етапах розвитку економічної системи: генерація знань - створення та поширення технологій - створення інноваційної продукції.

Зростання інтелектуального капіталу та ефективність його використання визначають перспективи щодо розвитку економіки тієї чи іншої країни. На сучасному етапі, питання пов'язані з управлінням інтелектуального капіталу та його складовими, $\epsilon$ одними із найбільш актуальних у науковому середовищі. Вивчивши дані теорії інтелектуального капіталу, структуру інтелектуального капіталу, пропоновану різними вченими, запропоновано нову складову інтелектуального капіталу підприємства управлінський капітал.

1. Базилевич В.Д. Інтелектуальна власність: підручник. К.: Знання, 2006. 431 с.

2. Баранчеев В. Управление знаниями: учебное пособие (журнал “Маркетинг”. Специальный выпуск № 29). М.: Центр маркетинговых исследований и менеджмента, 2005. 144 с.

3. Варфоломеева Ю.А. Интеллектуальная собственность в условиях инновационного развития: [монография]. М. : Ось-89, 2006. 144 с.

4. Єременко А.В. Інтелектуальна власність. Наука та інноващії. 2008. №7. С. 5-9.

5. Ілляшенко С.М. Проблеми i перспективи ринково-орієнтованого управління інноваційним розвитком. Суми: ТОВ “Друкарський дім “Папірус”, 2011. 644 с.

6. Ілляшенко С. Сутність, структура i методичні основи оцінки інтелектуального капіталу підприємства. Економіка Украӥни. 2008. № 11. С. 16-26.

7. Кендюхов О. Сутність і зміст організаційно-економічного механізму управління інтелектуальним капіталом підприємства. Економіка Украӥни. 2005. № 2. С. 33-41.

8. Левіна І.В. Інтелектуальний капітал: концептуальні основи відтворення: автореф. дис. на здобуття наук. ступеня канд. екон. наук : спец. 08.00 .04 "Економіка та управління підприємствами". Донецьк, 2011.20 с.

9. Мазарчук А.Ю., Ткач І.І. Аналіз структури інтелектуального капіталу підприємства. Вісник Хмельнищького наиіонального університету. Серія “Економічні науки”. 2010. № 6. Т. 4. С. 336-339.

10. Мельник Л.Г., Ильяшенко С.Н., Касьяненко В.А. Экономика информации и информационные системы предприятия: учебн. пособ. / Л.Г. Мельник, Сумы : ИТД “Университетская книга”, 2004. $400 \mathrm{c}$.

11. Просвирина И.И. Интеллектуальный капитал: новый взгляд на нематериальные активы. Финансовый менеджмент. 2004. № 4. С. 45-51.

12. Терон І.В. Інтелектуальний капітал як основне джерело багатства в постіндустріальному суспільстві. Формування ринкових відносин в Украӥні. 2007. № 7. С. 90-94.

13. Цыганов В.В., Бродин В.А., Шишкин Г.Б. Интеллектуальные предприятия. М. : Университетская книга, 2004. 345 с.

1. Bazylevych, V. Intellectual property, Znannia, 2006.

2. Barancheev, V. Management knowledges, Tsentr marketingovykh issledovaniy i menedzhementa, 2005.

3. Varfolomeeva, Yu. Intellectual property is in the conditions of innovative development, Os-89, 2006.

4. Yeremenko, A.V. “Intellectual property. ” Nauka ta innovatsii, no 7, 2008, pp. 5-9.

5. Illiashenko, S.M. Problems and prospects market oriented management innovative development, TOV "Drukarskyi dim "Papyrus", 2011.

6. Illiashenko, S. "Essence, structure and methodical bases of estimation of intellectual capital of enterprise." Ekonomika Ukrainy, no. 11, 2008, pp. 16-26. 
7. Kendiukhov, O. "Essence and maintenance organizationally economic to the mechanism of management of enterprise an intellectual capital", Ekonomika Ukrainy, no. 2, 2005, pp. 33-41.

8. Levina, I. Intellectual capital: conceptual bases of recreation, Thesis abstract of Cand. Sc. (Econ.), 08.00.04, 2011.

9. Mazarchuk, A.Yu., and I.I. Tkach. "Analysis of intellectual capital of enterprise structure." Visnyk Khmelnytskoho natsionalniho universytetu, no. 6, vol. 4, 2010, pp. 336-339.

10. Melnyk, L.G., Iliashenko, S.N., and V.A. Kasianenko. Economy of information and informative systems of enterprise, ITD "Universitetskaia kniga", 2004.

11. Prosvirina, I.I. "Intellectual capital the New look to the immaterial assets." Finansovyy menedzhement, no. 4, 2004, pp. 45-51.

12. Teron, I.V. "Intellectual capital as basic source of riches in postindustrial society." Formuvannia rynkovykh vidnosyn v Ukraini, no. 7, 2007, pp. 90-94.

13. Tsyganov, V.V., Brodin, V.A., and G.B. Shishkin. Intellectual enterprises, Universitetskaia kniga, 2004.

\title{
УДК 338.48
}

doi: 10.15330/apred.1.15.48-53

Мендела І.Я.

АУТСОРСИНГ В ДІЯЛЬНОСТІ ГОТЕЛЬНИХ ПІДПРИЄМСТВ

\author{
ДВНЗ “Прикарпатський національний університет \\ ім.В.Стефаника", \\ Міністерство освіти і науки України, \\ факультет туризму, \\ кафедра готельно-ресторанної та курортної справи, \\ вул. Галицька, 201б, м. Івано-Франківськ, \\ 76008 , Україна, \\ тел.: 0342778801, \\ e-mail: mendela_i@ukr.net
}

\begin{abstract}
Анотація. В статті проаналізовано особливості аутсорсингу в готельному бізнесі. Аутсорсинг передбачає наявність бізнес-процесів, які передаються на базі контракту тривалого періоду іншій організації, що спрощує будь-яку сферу діяльності, яка не є основною для готелю. Але, природно, передача певних функцій на аутсорсинг передбачає і наявність деяких ризиків для готельного підприємства. Найчастіше на аутсорсинг в готелі передаються послуги 3 клінінгу. Проте можливим $\epsilon$ ведення бухгалтерського обліку, організація харчування співробітників, навчання молодих співробітників, автотранспортні послуги тощо.

Конкуренція на відкритому ринку, де визначальну роль відіграють вже не тільки співвідношення ціни і якості готельних послуг, а й можливості найкращого задоволення потреб гостей, що скорочує час виходу на ринок нових додаткових послуг, володіння інтелектуальною власністю та інші переваги готелю, змушує менеджерів використовувати нові концепції управління, які охоплюють такі поняття, як інфра- та інтраменеджмент. На сьогодні господарювання вітчизняних підприємств готельного господарства характеризується нестійкими тенденціями розвитку, що обумовлюється сезонними коливаннями попиту i неможливістю створення запасів специфічного продукту - готельної послуги, тому необхідний ефективний менеджмент готелю.

В процесі управління готелем при використанні інтра- чи інфраменеджменту аутсорсинг можна розділити на два типи - інтелектуальний (IT-аутсорсинг, управління знаннями, менеджмент персоналом, юридичний супровід) та виробничий (передача організації-партнеру повного циклу виробництва певного продукту або його частини). Аутсорсинг сфери послуг пов'язаний 3 підвищенням вимог до рівня компетентності менеджерів i повсюдним
\end{abstract}

